\title{
Talent pedagogiczny czy mistrzostwo w zawodzie? Być skutecznym nauczycielem-wychowawca
}

\section{Pedagogical Talent or Mastery in the Profession? Being an Effective Teacher and Educator}

\begin{abstract}
ABSTRAKT
Celem artykułu jest zwrócenie uwagi na potrzebę ciqgłłego doskonalenia nauczycieli i wychowawców w szybko zmieniających się warunkach życia. Rozwój nowych technologii oraz ambiwalencja preferowanych norm i wartości powodujq konieczność nie tylko podqżania za dokonującymi się zmianami, ale też zapobiegania ich niepożq̨danym skutkom. Potrzeba do tego odpowiednich kompetencji. Przedmiotem analizy uczyniono więc zagadnienia talentu pedagogicznego, profesjonalizmu i mistrzostwa w zawodzie.

Problematyka badań obejmuje przeglad stanowisk wybranych pedagogów wobec zagadnień talentu pedagogicznego, profesjonalizmu, mistrzostwa w zawodzie oraz analizę oczekiwań, kierowanych pod adresem nauczycieli i wychowawców, ich kwalifikacji i kompetencji. Zastosowano metodę krytycznej analizy literatury przedmiotu.

Dla współczesnych nauczycieli i wychowawców bardziej istotne jest dążenie do profesjonalizmu w zawodzie, niż posiadanie talentu pedagogicznego. Ten ostatni dany jest tylko nielicznym, natomiast od
\end{abstract}

StOWA KLUCZOWE talent pedagogiczny, mistrzostwo w zawodzie, profesjonalizm, nauczyciel, wychowawca, doskonalenie zawodowe

\section{KEYWORDS}

pedagogical talent, mastery of the profession, professionalism, teacher, educator, professional development

SPI Vol. 24, 2021/3

ISSN 2450-5358 e-ISSN 2450-5366 DOI: 10.12775/SPI.2021.3.006

Nadesłano: 3.07.2021 Zaakceptowano: 18.10.2021

Artykuły i rozprawy 
ogółu nauczycieli i wychowawców oczekuje się skutecznych oddziaływań. Mistrzostwo w zawodzie jest osiagalne dla każdego, zwłaszcza jeśli traktuje się swoja pracę jako powołanie i pasię. Należy zatem już w okresie studiów uświadamiać przyszłym nauczycielom i wychowawcom, jak ważne jest ciqgłe dokształcanie i doskonalenie się w zawodzie.

\section{ABSTRACT}

The purpose of the article is to draw attention to the need for the continuous professional development of teachers and educators in the rapidly changing conditions of modern life. The development of new technologies and ambivalence of the preferred norms and values make it necessary not only to follow the changes, but also to prevent their undesirable effects. It requires achieving appropriate competencies. Therefore, the subject of analysis is the pedagogical talent, professionalism and mastery of the profession.

The research problem includes an overview of the positions of selected educators towards pedagogical talent, professionalism, mastery of the profession and the analysis of expectations directed at teachers and educators, their qualifications and competences. The method of critical analysis of the literature on the subject was applied.

For contemporary teachers and educators, it is more important to strive for professionalism in the profession than to have pedagogical talent. The latter is given only to a few, while effective interactions are expected from all teachers and educators. Mastery of the profession is achievable for everyone, especially if they consider their work as a vocation and passion. Therefore, during the period of study, future teachers and educators should be made aware of the importance of continuous training and improvement in the profession.

\section{Wprowadzenie}

Nauczyciel pełni istotną rolę w życiu społecznym - spoczywa na nim odpowiedzialność za kształtowanie młodego pokolenia. Odpowiedzialność tę dzieli z rodzicami uczniów, niemniej to jednak od niego, jako specjalisty, oczekuje się skutecznego oddziaływania na dzieci i młodzież. Od tego, kim jest nauczyciel, jakie ma umiejętności i predyspozycje oraz na ile jest zaangażowany w swoją pracę, zależą osiągane efekty. Już Jean-Jacques Rousseau w wieku XVIII, 
zwracając się do nauczycieli, przestrzegał: „Pamiętaj, zanim odważysz się przedsięwziąc formułowanie człowieka, musisz przedtem sam stać się człowiekiem, musisz z samego siebie uczynić przykład, którym powinieneś być dla ucznia" (Rousseau 1955: 92). Na początku XX wieku Jan Władysław Dawid pisał: „Kierowniczym czynnikiem wychowania jest to, czem jest nauczyciel, a raczej za co się ma i czem jeszcze chciałby być. Dlatego w żadnym zawodzie człowiek nie ma tak wielkiego znaczenia, jak w zawodzie nauczycielskim" (Dawid 1932: 6). Twierdził, że tylko dobry nauczyciel może dobrze nauczyć i wychować powierzonych sobie uczniów. Aby jednak mógł sprostać oczekiwaniom społecznym, powinien wciąż się doskonalić. Słowa pedagoga sprzed niemal stu lat do dzisiaj nie straciły aktualności. Dlatego celem podejmowanych w niniejszym opracowaniu rozważań jest zwrócenie uwagi na potrzebę ciągłego pogłębiania przez nauczycieli i wychowawców wiedzy i rozwijania umiejętności, niezbędnych w ich codziennej pracy. Podstawą skutecznych oddziaływań dydaktyczno-wychowawczych są posiadane przez nauczycieli kompetencje. Przedmiotem analizy uczyniono więc zagadnienia talentu pedagogicznego, profesjonalizmu i mistrzostwa w zawodzie. Chociaż posiadanie talentu niewątpliwie ułatwia wykonywanie obowiązków, znacznie ważniejsze jest dążenie do osiągnięcia profesjonalizmu i mistrzostwa w zawodzie. Tym bardziej, że talent posiadają tylko nieliczni, natomiast każdy nauczyciel, zaangażowany w pracę, traktujący swój zawód jako powołanie i pasję, może się stać mistrzem - profesjonalistą w zawodzie. Problematyka badań obejmuje również analizę oczekiwań kierowanych pod adresem nauczycieli i wychowawców. Materiał wykorzystany w publikacji zgromadzono przy zastosowaniu metody krytycznej analizy literatury przedmiotu.

\section{Talent pedagogiczny, mistrzostwo, profesjonalizm}

W polskiej myśli pedagogicznej wiele miejsca poświęcono nauczycielowi i jego roli w procesie edukacji. Początkowo sądzono, że aby być dobrym nauczycielem, trzeba mieć „duszę nauczycielstwa” lub talent pedagogiczny. Dawid uważał, że istotą nauczycielskiego powołania jest miłość dusz ludzkich, polegająca na tym, że „człowiek wychodzi poza siebie, czyni coś bezinteresownie dla drugiego; jest to miłość dusz, bo przedmiotem jej jest wewnętrzna duchowa treść człowieka, 
jego dobro moralne, oświecenie i udoskonalenie jako istoty duchowej” (Dawid 1932:11). Uzupełniają ją inne zalety etyczne: potrzeba doskonałości, poczucie odpowiedzialności i obowiązku, wewnętrzna prawdziwość i moralna odwaga oraz skłonność do społecznego oddziaływania. Cechy te stanowią „dar indywidualny, powołanie, przejaw wyższego duchowego w człowieku pierwiastka" (Dawid 1932: 36). Natomiast Zygmunt Mysłakowski posługiwał się terminem „talent pedagogiczny”, który definiował jako „wrodzoną dyspozycję psycho-fizjologiczną, szczególnie sprzyjającą wypełnianiu zadań wychowawczych, dzięki której osobnik pewne szczególne typy działalności lub produkcji uprawiać może w sposób bardziej wydajny, niż w przypadku zajmowania się czym innym” (Mysłakowski 1959: 61). Za najważniejszą cechę tak rozumianego talentu uznał umiejętność bycia $z$ drugą osobą w stałym kontakcie. Do innych cech zaliczył: wrodzoną żywość wyobraźni, która umożliwia wczucie się w stany psychiczne innych osób, zdolność do obserwacji ruchów ekspresyjnych, instynkt rodzicielski, ekspresję uczuć i ekstrawersję, czyli nastawienie na zewnątrz. Sądził, że wrodzony talent pedagogiczny można świadomie doskonalić i rozwijać (Mysłakowski 1959: 66-67). Zupełnie inaczej definiował talent pedagogiczny Stefan Szuman. Traktował go jako zbiór pewnych zdolności o dużym natężeniu (cech psychicznych, dzięki którym człowiek wykonuje określone czynności szczególnie dobrze), umiejętność oddziaływania na innych oraz bogactwo własnej osobowości (Szuman 1959: 78-79). Sądził jednak, że „nie istnieje jakaś jedna odrębna, wrodzona cecha, która by była swoistym i zasadniczym dyspozycyjnym podłożem tego talentu (...) mylny jest pogląd naiwny, że człowiek nosi w sobie jakieś oddzielne, wrodzone, potencjalne talenty" (Szuman 1959: 81). Jego zdaniem nie można mówić o wrodzonym talencie pedagogicznym, jednak człowiek wyposażony jest w pewne cechy osobowości, umożliwiające w korzystnych warunkach rozwój tego talentu. Nikt nie rodzi się nauczycielem, ale może się nim stać. Dobry pedagog powinien posiadać następujące cechy charakteru: miłość, takt, etykę oraz wypracować swój skuteczny styl wychowania (Szuman 1959: 81). $Z$ twierdzeniami o powołaniu do zawodu nauczycielskiego i istotnej roli talentu pedagogicznego zdecydowanie zerwał Stanisław Dobrowolski, który pod koniec lat 50. XX wieku zwrócił uwagę na dominujące znaczenie $w$ pracy nauczycieli wiedzy i umiejętności dydaktyczno-wychowawczych (Dobrowolski 1959). 
W literaturze pedeutologicznej, zwłaszcza ostatnich lat, często występują określenia „mistrzostwo w zawodzie” i „profesjonalizm pedagogiczny" (Ratajek 2005; Ziaziun 2005; Szkolak 2013, 2016; Szumiec 2021). Nie są to jednak pojęcia nowe. Do kryteriów mistrzostwa pedagogicznego już w połowie XX wieku Wincenty Okoń zaliczył: znajomość zasad wychowania i nauczania oraz umiejętność ich zastosowania, dobór odpowiednich metod pracy (aby uniknąć lub zlikwidować niepowodzenia dydaktyczne), stopień upodmiotowienia wychowanków i spontaniczne realizowanie przez nich określonego programu samowychowania i samokształcenia (Okoń 1959: 21). Obecnie mistrzostwo definiowane jest jako „wyróżniająca się, na wysokim poziomie, wybitna działalność w dziedzinie dydaktycznej lub wychowawczej (...) proces zbliżania się do czegoś doskonałego" (Galant 1993: 200-201) lub też „spełnianie wysokich standardów: poznawczych, działaniowych i etycznych" (Kwiatkowska 2008: 167). Olena Bocharova uznała mistrzostwo za „najwyższy poziom działalności pedagogicznej, która wyraża się w twórczości nauczyciela, w stałym doskonaleniu sztuki nauczania, wychowania i samorozwoju człowieka”. Jej zdaniem na osiągnięcie mistrzostwa pedagogicznego wpływa wiele czynników tworzących układ wzajemnie sprzężonych cech. Do czynników tych, powołując się na prace Lidji Kajdałowej, zaliczyła: kompetencje profesjonalne, cechy osobowości, takt pedagogiczny, technikę pedagogiczną, twórczość pedagogiczną, orientację humanistyczną, kulturę komunikacji oraz zdolności pedagogiczne (Bocharova 2016: 206-207).

Zdaniem Beaty Jakimiuk profesjonalizm nauczyciela wyznaczają: posiadane kwalifikacje (uprawnienia do wykonywania zawodu), kompetencje związane $\mathrm{z}$ rozwojem osobistym i zawodowym nauczyciela (nie zawsze potwierdzone odpowiednimi dokumentami) oraz ich wykorzystanie $\mathrm{w}$ kierunku wspierania rozwoju i motywacji uczniów, budowania ich podmiotowości oraz poczucia własnej wartości (Jakimiuk 2016: 49). O profesjonalizmie świadczy „umiejętność funkcjonowania i skutecznego działania w sytuacjach nietypowych” oraz „podejmowanie właściwych działań w konkretnych okolicznościach" (Jakimiuk 2019: 120). Zdaniem Renate Girmes profesjonalny nauczyciel współczesnej szkoły musi spełniać szereg wymagań: „być ekspertem stale rozwijającym i przebudowującym ofertę dydaktyczną tak, by zwiększać jej relewantność i reprezentatywność wobec 
stojących przed nim zadań; kompetentnie kreować środowisko kształcenia, w którym uczeń zdobytą wiedzę będzie wykorzystywał podczas rozwiązywania stawianych przed nim zadań, a także będzie potrafił wykorzystać ją w nowych sytuacjach; prezentować postawę gotowości do nieustannego kształcenia się; umieć stworzyć odpowiedni klimat i otoczenie, by zachęcać uczniów do nauki; stawiać przed uczniami zadania, uwzględniając ich pochodzenie społeczne, warunki życia, indywidualne zdolności; umieć dokumentować, oceniać, analizować, wyciągać wnioski i planować zarówno pracę uczniów, jak i swoją, na którą powinien dodatkowo umieć spojrzeć z dystansem i przyjąć postawę refleksyjną wobec własnej działalności” (za: Opłocka 2011: 14-15). Nauczyciel profesjonalista nie może być przeciętny lub nudny, nie może popadać w rutynę, winien potrafić wskazać uczniom nowe perspektywy myślenia i działania, pobudzić ich do aktywności i twórczości. Sam również jest nastawiony na ciągły rozwój i doskonalenie się. Profesjonalizm nie jest stanem, ale czymś, co się stale kształtuje. Wymaga ciągłych starań, refleksji, interpretacji zdarzeń, analizy własnego postępowania (Witkowski 2018: 135). Jego istotą jest „nieustanne poszukiwanie, rozwój, przekraczanie schematów, autentyczne zainteresowanie drugim człowiekiem, dostrzeganie i wydobywanie z każdego ucznia jego zdolności, talentów, możliwości” (Jakimiuk 2019: 121). Najważniejsze jednak jest, aby nauczyciel pozostał człowiekiem, gdyż jak pisał Julian Radziewicz: „(...) ten, kto prowadzi - jest przewodnikiem. Ten, kto jest wzorem - to przede wszystkim autorytet. Ten, kto współdziała bywa partnerem. Ten, kto uczy skutecznie - jest po prostu mistrzem. A naprawdę ten, kto kocha, lubi, szanuje - to przede wszystkim prawdziwy, normalny człowiek. Właśnie człowiek, a więc: przewodnik, autorytet, partner, mistrz" (Radziewicz 1996: 28).

\section{Oczekiwania wobec nauczycieli i wychowawców}

Oczekiwania wobec nauczycieli i wychowawców zmieniały się na przestrzeni wieków i lat w związku z następującymi przemianami społeczno-politycznymi i gospodarczymi. Jednak bez względu na te uwarunkowania niemal zawsze spodziewano się, że nauczyciele pomogą rodzicom w przygotowaniu młodego pokolenia do podjęcia obowiązków dorosłego życia. Wiązało się to z przekazywaniem 
wiedzy oraz wychowywaniem do preferowanych w społeczeństwie wartości. Na ziemiach polskich wyjątek stanowił okres zaborów, kiedy to odpowiedzialność za wychowanie dzieci i młodzieży, a także $\mathrm{w}$ wielu przypadkach ich nauczanie, spoczywała w głównej mierze na rodzinie (Kalinowska-Witek 2012). Po odzyskaniu niepodległości w 1918 roku nauczyciele zaczęli odzyskiwać swoją pozycję społeczno-zawodową, ale jednocześnie musieli sprostać większym wymaganiom, zwłaszcza w zakresie merytorycznego przygotowania do zawodu. Zagadnienia te, będące przedmiotem zainteresowania autorki artykułu, zostały szerzej omówione w kilku publikacjach (Kalinowska-Witek 2014, 2015, 2016, 2019).

Obecnie szybko zmieniająca się rzeczywistość oraz rozwój nowych technologii z jednej strony stwarzają niespotykane dotychczas możliwości rozwoju dzieci i młodzieży, z drugiej - stanowią źródło nowych zagrożeń. Rodzice często nie zdają sobie z nich sprawy, więc tym bardziej nie potrafią im zapobiegać i przeciwdziałać. Gdy wydarzy się jakaś przykra sytuacja, oczekują pomocy i wsparcia od nauczycieli i wychowawców, którzy na co dzień pracują z ich dziećmi. Nauczyciele jednak często sami czują się zagubieni i niewystarczająco kompetentni, aby sprostać tym oczekiwaniom. Niewątpliwie posiadają odpowiednie kwalifikacje, często uzupełniane podczas studiów podyplomowych, różnego rodzaju szkoleń i kursów. Sama wiedza jednak nie wystarczy, istotne są również umiejętności praktyczne, a na ich rozwijanie przeznacza się w czasie tego typu szkoleń znacznie mniej czasu. Ważna jest też praca nad sobą, przezwyciężaniem własnych słabości.

Z badań opublikowanych przez Justynę Miko-Giedyk w 2014 roku, poświęconych oczekiwaniom wobec nauczycieli w środowisku wiejskim, wynika, że zgłaszane przez respondentów postulaty dotyczą bardzo zróżnicowanych kompetencji i zachowań. Wśród oczekiwań można wyróżnić kilka kategorii obejmujących: cechy osobowościowe (np. cierpliwość, życzliwość, serdeczność, otwartość na innych, troskliwość, zamiłowanie do pracy z dziećmi), kompetencje wychowawcze (posiadanie autorytetu, nienaganna postawa moralna, bycie wiarygodnym), odpowiednie wykształcenie (wiedza i umiejętności, np. odpowiednie podejście do dzieci), umiejętności menedżerskie (organizacyjne), zdolności przywódcze, oczekiwania w zakresie wyrównywania szans edukacyjnych uczniów oraz umiejętności 
integracyjne (organizowanie współpracy w środowisku lokalnym). Spełnienie tych postulatów niejednokrotnie przekracza możliwości nawet doświadczonych nauczycieli, natomiast dla tych, którzy dopiero rozpoczynają pracę pedagogiczną, są one wręcz niemożliwe do realizacji (Miko-Giedyk 2014: 54). Można przypuszczać, że oczekiwania wobec nauczycieli zatrudnionych $\mathrm{w}$ szkołach miejskich będą analogiczne lub nawet większe.

Realizacja niektórych z oczekiwań może być niemożliwa również dlatego, że nie wszystko zależy od nauczycieli. Są oni elementem systemu oświatowego, dość mocno zbiurokratyzowanego, który tak łatwo nie podlega przemianom. Nauczyciele muszą więc niejednokrotnie dostosowywać się do stawianych im odgórnie wymagań (Klus-Stańska 2013: 436). Niemniej jednak od nich, ich postawy wobec własnej roli zawodowej i samych uczniów zależy atmosfera w klasie szkolnej, ta zaś sprzyja realizacji zadań opiekuńczo-wychowawczych bądź je utrudnia.

Zawód nauczyciela nie jest łatwy, ale jego wykonywanie może przynieść wiele satysfakcji. Kandydaci do zawodu powinni być jednak wyposażeni w odpowiednie kompetencje: poznawcze, sprawnościowe, społeczno-moralne i psychologiczne (Sobieszczyk, Wojciechowska 2015: 51). Dzięki nim nauczyciele będą mogli sprostać oczekiwaniom rodziców i samych uczniów przynajmniej w zakresie najważniejszych kwestii: indywidualizacji oddziaływań, rozwijania zainteresowań, wspierania mocnych stron dzieci i młodzieży, przekazywania wiedzy i kształtowania umiejętności, pomocy w przezwyciężaniu trudności dydaktycznych i wychowawczych, udzielania pomocy w sytuacjach trudnych, przezwyciężania trudności adaptacyjnych, nawiązywania pozytywnych relacji $\mathrm{w}$ grupie rówieśniczej i innych sytuacjach, w których uczniowie potrzebują wsparcia.

\section{Potrzeba ciagłego dokształcania i doskonalenia zawodowego nauczycieli}

Nie każdy nauczyciel posiada talent pedagogiczny, jednak wszyscy pedagodzy powinni dążyć do tego, aby coraz lepiej funkcjonować w zawodzie i wypełniać przyjęte na siebie obowiązki. Już Wincenty Okoń w połowie ubiegłego wieku pisał o nauczycielu: „chcąc dawać innym - musi on sam wiele posiadać, chcąc kształcić innych - musi 
sam być gruntownie wykształcony, chcąc czynić innych lepszymi musi być sam dobry" (Okoń 1959: 14). Natomiast Bogdan Suchodolski dodawał: „Umiejętności pedagogiczne są wykształcalne, a mistrzostwo pedagogiczne jest osiaggalne, lecz jedynie w drodze wnikliwego studiowania teorii (...) oraz rozwijania umiejętności stosowania jej w praktyce" (Suchodolski 1973: 630). Również Maria Grzegorzewska podkreślała potrzebę ciągłego dokształcania się nauczycieli i wychowawców: „Prawdziwie wartościowym człowiekiem jest ten, kto się całe życie uczy, kto się całe życie w pracy i przy pracy kształci z własnej woli, dlatego, że tak chce i że inaczej wartości swojej pracy zrozumieć nie może" (Grzegorzewska 2002: 51).

Analizując bogaty dorobek polskiej pedeutologii, wyróżnić można różne podejścia do edukacji nauczycieli. Okoń scharakteryzował następujące koncepcje: kompetencyjną, personalistyczną i progresywną (Okoń 1988). Henryka Kwiatkowska opisała trzy orientacje w edukacji nauczycieli: technologiczną, humanistyczną i funkcjonalną (Kwiatkowska 2008: 48-63). Tadeusz Lewowicki dokonał zestawienia występujących na przestrzeni lat modeli i podstawowych nurtów edukacji nauczycielskiej. Zaliczył do nich następujące modele: ogólnokształcący, personalistyczny, pragmatyczny, specjalistyczny, progresywny, wielostronny, samorozwoju i samokształcenia, edukacji permanentnej, krytycznej diagnozy własnej wiedzy i niewiedzy (Lewowicki 2007: 48-51). W ostatnich latach pojawiły się też nowe propozycje dotyczące sposobów kształcenia nauczycieli. Wśród nich na szczególną uwagę zasługują m.in.: nurt profesjonalnego artyzmu, koncepcja nauczyciela-badacza - uczestnika i twórcy zdarzeń edukacyjnych, a jednocześnie ich obserwatora (prowadzącego badania w działaniu) oraz koncepcje: transformatywnego intelektualisty, pedagoga wyemancypowanego i postpozytywistycznego praktyka (Szempruch 2016: 40-41). Preferowany sposób kształcenia i stawiane nauczycielom wymagania zależą od przyjętej wizji szkoły i nauczyciela oraz jego roli w procesie edukacji.

W sytuacji pojawiających się wciąż nowych wyzwań i zagrożeń wiedza zdobyta na studiach nie wystarczy do efektywnego wypełniania obowiązków nauczycielskich i wychowawczych. Dzieci i młodzież podlegają różnym oddziaływaniom, często w pewnych zakresach posiadają wiedzę znacznie szerszą niż ich nauczyciele. Rola nauczyciela i jego priorytety muszą więc ulec zmianie. Spośród wielu 
kompetencji, umożliwiających nauczycielowi wypełnianie obowiązków zawodowych, w ostatnich latach na plan pierwszy wysuwają się kompetencje komunikacyjne. Dzięki bardziej efektywnemu porozumiewaniu się z uczniami i ich rodzicami nauczyciel będzie miał szansę lepiej poznać wychowanków, ich potrzeby oraz trudności i w odpowiedniej chwili podjąć niezbędne oddziaływania profilaktyczne lub interwencyjne. Może mieć też nadzieję, że zostanie wysłuchany przez młodzież i dzięki temu zyska możliwość bardziej skutecznego na nią wpływu. Będzie to możliwe, jeśli nauczyciel będzie przekonany, że „najwyższą wartością dla niego jest dobro dziecka, rozumiane najpierw jako prymat rozwoju jego osobowości w miejsce prymatu jego wiedzy. Ucząc i wychowując, tzn. wywołując zamierzone zmiany w osobowości wychowanków, wspiera swoją pracą rodziców. Wraz z nimi współodpowiada za zdrowie, integralny rozwój osobowy swoich wychowanków, za przygotowanie ich do życia w społeczeństwie zróżnicowanym światopoglądowo i etycznie" (Rusiecki 2004: 9).

Dokształcanie się i doskonalenie umiejętności jest też sposobem na zapobieganie wypaleniu zawodowemu, a jeśli już się pojawi, metodą na przezwyciężanie tego problemu (Kocór 2019; Kordziński 2019).

\section{Podsumowanie - wnioski i implikacje praktyczne}

W literaturze pedagogicznej, a zwłaszcza pedeutologicznej, znaleźć można wiele rozważań na temat tego, kim powinien być nauczyciel, jakie zadania ma do spełnienia, jakie kompetencje umożliwią mu skuteczną pracę z dziećmi i młodzieżą (Sokołowska 2007; Kwiatkowski 2008; Mihułka 2018). W ostatnich latach pojawiły się liczne publikacje poświęcone zagadnieniu profesjonalizmu pedagogicznego i mistrzostwa w zawodzie. Na uwagę zasługują zwłaszcza opracowania Bogusławy D. Gołębniak (2010), Bogusławy D. Gołębniak i Beaty Zamorskiej (2014), Moniki Noworolnik-Mastalskiej (2013), Urszuli Opłockiej (2011, 2014), Przemysława P. Grzybowskiego (2006), Anny Weissbrot-Koziarskiej i Joanny Janik (2006) oraz wielu innych. Społeczeństwo, a zwłaszcza rodzice, stawiają nauczycielom i wychowawcom coraz wyższe wymagania. Oczekują rzetelnej wiedzy oraz umiejętności jej przekazywania i zastosowania w codziennej pracy dydaktyczno-wychowawczej. Wymagają odpowiedniego podejścia do dziecka, pomocy w rozwiązywaniu pojawiających się problemów, 
dobrego przygotowania do dorosłego życia. $Z$ drugiej jednak strony darzą pedagogów coraz mniejszym szacunkiem i zaufaniem. Są często bardzo krytyczni wobec ich pracy i wymagań stawianych uczniom - ich dzieciom. Na przestrzeni lat, szczególnie w II połowie XX wieku, zawód nauczyciela stopniowo się dewaluował. Obecnie realia pracy nauczycieli, brak selekcji na studia nauczycielskie i do zawodu (Kwiatkowski 2008: 29) lub wręcz w wielu przypadkach selekcja negatywna, uniemożliwiają spełnianie słusznych oczekiwań społecznych, wysuwanych w stosunku do nauczycieli. Stosunek władz państwowych do tej grupy zawodowej też nie ułatwia realizacji zadań. Niedostatki w organizacji szkolnictwa i kształceniu kadry pedagogicznej ujawniają się zwłaszcza w sytuacjach trudnych. $Z$ takimi przyszło nam się zmierzyć w dobie pandemii COVID-19, kiedy część nauczycieli z trudem radziła sobie z realizacją obowiązków zawodowych. Jednak niektórzy pedagodzy bardzo szybko odnaleźli się w nowej dla wszystkich sytuacji zdalnego nauczania. Zazwyczaj byli to ci, którzy także w ubiegłych latach mogli się poszczycić dużymi (choć nie zawsze odnotowywanymi i docenianymi przez władze szkolne) osiągnięciami w pracy z dziećmi i młodzieżą - osoby rzeczywiście zaangażowane, dla których nauczanie zawsze stanowiło pasję, a nawet treść życia. Właśnie o nich można powiedzieć, że są to profesjonaliści, mistrzowie w swoim zawodzie.

Studentom kierunków nauczycielskich warto uświadamiać, że okres studiów jest nie tyko czasem zdobywania wiedzy, ale też rozwijania umiejętności, zdobywania doświadczeń, poszukiwania pasji, określania własnych preferencji zawodowych. Przyszli pedagodzy powinni $\mathrm{w}$ jak największym stopniu się angażować $\mathrm{w}$ działalność wychowawczą w czasie praktyk studenckich, podejmować wolontariat, poszukiwać nowych możliwości rozwijania i doskonalenia swoich umiejętności. Jeśli w czasie studiów rozwiną w sobie zamiłowanie do pracy z dziećmi i młodzieżą oraz postawę ciągłego doskonalenia się i dążenia do osiągnięcia mistrzostwa w zawodzie, podjęta w przyszłości praca zawodowa z pewnością przyniesie im satysfakcję, pomimo stosunkowo niskiego wynagrodzenia i coraz niższego prestiżu społecznego. 


\section{Bibliografia}

Bocharova O. (2016). Mistrzostwo pedagogiczne jako czynnik kluczowy dziatalności pedagogicznej nauczycieli na Ukrainie, „Acta Scientifica Academiae Ostroviensis. Sectio A. Nauki Humanistyczne, Społeczne i Techniczne”, t. 1, nr 7, s. 203-215.

Dawid J.W. (1932). O duszy nauczycielstwa, Warszawa: Wydawnictwo Nasza Księgarnia Sp. AKC ZNP.

Dobrowolski S. (1959). Struktury umystów nauczycieli, Warszawa: Wydawnictwa Szkolne i Pedagogiczne.

Galant J. (1993). Rozważania o mistrzostwie pedagogicznym, „Nowa Szkoła”, nr 4, s. 200-206.

Gołębniak B.D. (2010). Ku pedeutologii refleksyjnej, [w:] Etyka i profesjonalizm w zawodzie nauczyciela, red. J. Michalak, Łódź: Wydawnictwo Uniwersytetu Łódzkiego, s. 143-165.

Gołębniak B.D., Zamorska B. (2014). Nowy profesjonalizm nauczycieli. Podejścia - praktyka - przestrzeń rozwoju, Wrocław: Wydawnictwo Dolnośląskiej Szkoły Wyższej.

Grzegorzewska M. (2002). Listy do Mtodego Nauczyciela. Cykl I-III, Warszawa: Akademia Pedagogiki Specjalnej im. Marii Grzegorzewskiej.

Grzybowski P.P. (2006). Profesjonalizm nauczyciela - a cóż to takiego?, „Rocznik Pedagogiczny", t. 29, s. 131-137.

Jakimiuk B. (2016). Tworzenie relacji interpersonalnych jako podstawa i fundament profesjonalizmu nauczycieli, [w:] Rozwój nauczyciela od wczesnej dorostości do późnej starości, red. J.M. Łukasik, N.G. Pikuła, K. Jagielska, Kraków: Oficyna Wydawnicza „Impuls”, s. 49-64.

Jakimiuk B. (2019). Sukcesy zawodowe i profesjonalizm w doświadczeniach nauczycieli, „Annales Universitatis Mariae Curie-Skłodowska. Sectio J”, t. 32 , nr 4, s. 117-131.

Kalinowska-Witek B. (2012). Oczekiwania wobec szkoty elementarnej $i$ średniej na przetomie XIX i XX wieku (w świetle wybranych czasopism kobiecych Królestwa Polskiego), [w:] Wychowawcza rola szkoty, red. J. Kirenko, T. Zubrzycka-Maciąg, D. Wosik-Kawala, Lublin: Wydawnictwo UMCS, s. 299-316.

Kalinowska-Witek B. (2014). Obowiazki wychowawcy klasy w szkotach średnich Drugiej Rzeczypospolitej, „Biuletyn Historii Wychowania”, nr 31, s. $113-130$.

Kalinowska-Witek B. (2015). Budowa rangi zawodu nauczyciela w swietle czasopisma "Przeglad Pedagogiczny” w latach 1918-1939, „Przegląd Historyczno-Oświatowy”, nr 1-2, s. 59-77.

Kalinowska-Witek B. (2016). Dla dobra szkoty i „dla dobra stużby”... Kwestie ustrojowe szkolnictwa $i$ sprawy zawodowe nauczycieli w czasopismach Towarzystwa Nauczycieli Szkót Srednich i Wyższych oraz Zwiazku Zawodowego Nauczycielstwa Polskich Szkót Średnich (1918-1939), Lublin: Wydawnictwo UMCS. 
Kalinowska-Witek B. (2019). Pragmatyka nauczycielska w świetle ustaw i rozporzadzeń ministerialnych z lat 1918-1939, „Edukacja - Technika Informatyka”, nr 2(28), s. 73-79.

Klus-Stańska D. (2013). Pozór w edukacji-dyskusja, [w:] Sprawcy i/lub ofiary dziatań pozornych wedukacji szkolnej, red. M. Dudzikowa, K. Knasiecka-Falbierska, Kraków: Oficyna Wydawnicza „Impuls”, s. 436-440.

Kocór M. (2019). Wypalenie zawodowe nauczycieli. Diagnoza, wsparcie, profilaktyka, Kraków: Wydawnictwo Societas Vistulana.

Kordziński J. (2019). Przeciwdziatanie wypaleniu zawodowemu, Warszawa: Wydawnictwo Wolters Kluwer.

Kwiatkowska H. (2008). Pedeutologia, Warszawa: Wydawnictwa Akademickie i Profesjonalne.

Kwiatkowski S.M. (2008). Oczekiwania spoteczne wobec nauczycieli - w kierunku szlachetnej utopii, [w:] Nauczyciel w świecie wspótczesnym, red. B. Muchacka, B. Szymański, Kraków: Oficyna Wydawnicza „Impuls”, s. $27-30$.

Lewowicki T. (2007). Problemy ksztatcenia i pracy nauczycieli, Warszawa-Radom: Wydawnictwo Instytutu Technologii Eksploatacji PIB.

Mihułka K. (2018). Osobowość nauczyciela a wptyw wychowawczy - ujęcie teoretyczne, „Języki Obce w Szkole”, nr 3, s. 119-125.

Miko-Giedyk J. (2014). Oczekiwania wobec nauczyciela oraz jego roli w środowisku wiejskim - w świetle wypowiedzi studentów pedagogiki urodzonych $i$ wychowanych na wsi, „Rozprawy Społeczne”, t. 8, nr 3, s. 48-56.

Mysłakowski Z. (1959). Co to jest „talent pedagogiczny”, [w:] Osoborwośc nauczyciela, red. W. Okoń, Warszawa: Państwowe Zakłady Wydawnictw Szkolnych, s. 57-68.

Noworolnik-Mastalska M. (2013). Rozwoój profesjonalny jako uczenie się w relacjach, „Studia Poradoznawcze”, nr 2, s. 64-84.

Okoń W. (1959). Problem osobowości nauczyciela, [w:] Osoborwość nauczyciela, red. W. Okoń, Warszawa: Państwowe Zakłady Wydawnictw Szkolnych, s. $5-28$.

Okoń W. (1988). Ksztatcenie nauczycieli w Polsce-stan i kierunki przebudowy, Warszawa-Kraków: Państwowe Wydawnictwo Naukowe.

Opłocka U. (2011). Na drodze do profesjonalizmu, Wrocław: Wydawnictwo Dolnośląskiej Szkoły Wyższej.

Opłocka U. (2014). Na drodze do profesjonalizmu, [w: ] Poprzez praktykę do profesjonalizmu. Przygotowanie do zawodu nauczyciela, red. B. Kutrowska, A. Pereświet-Sołtan, Wrocław: Wydawnictwo Dolnośląskiej Szkoły Wyższej, s. 66-100.

Radziewicz J. (1996). Autoportret pedagogiczny, „Edukacja i Dialog”, nr 4, s. $27-31$.

Ratajek Z. (2005). Nauczyciel akademicki - jego osobowe cechy i profesjonalne mistrzostwo, [w:] Psychologiczno-pedagogiczne ksztatcenie nauczycieli, red. E. Sałata, Radom-Warszawa: Wydawnictwo Instytutu Technologii Eksploatacji PIB, s. 32-42. 
Rousseau J.J. (1955). Emil, czyli o wychowaniu, t. 1, do druku przygotował F. Wnorowski, Wrocław: Zakład Narodowy im. Ossolińskich.

Rusiecki M. (2004). Karta odpowiedzialności i obowiqzzków nauczyciela, „Wychowawca", nr 10, s. 7-11.

Sobieszczyk M., Wojciechowska K. (2015). Praktyki pedagogiczne droga do mistrzostwa w zawodzie nauczyciela, „Przegląd Pedagogiczny”, nr 1, s. 51-60.

Sokołowska E. (2007). Jak być skutecznym i zadowolonym nauczycielem, Warszawa: Wydawnictwo Fraszka Edukacyjna.

Suchodolski B. (1973). Pedagogika. Podręcznik dla kandydatów na nauczycieli, Warszawa: Państwowe Wydawnictwo Naukowe.

Szempruch J. (2016). Modele ksztatcenia nauczycieli a zadania edukacji, „Studia z Teorii Wychowania", nr 4, s. 37-51.

Szkolak A. (2013). Mistrzostwo zawodowe nauczycieli wczesnej edukacji. Istota, treśc, uwarunkowania, Kraków: Wydawnictwo „Attyka”.

Szkolak A. (2016). Portret mistrza w zawodzie nauczyciela wczesnej edukacji, „Pedagogika Przedszkolna i Wczesnoszkolna”, nr 1(7), s. 39-50.

Szuman S. (1959). Talent pedagogiczny, [w:] Osobowość nauczyciela, red. W. Okoń, Warszawa: Państwowe Zakłady Wydawnictw Szkolnych, s. 73-108.

Szumiec M. (2021). Rozwój kompetencji osobowościowych jako istotny element rozwoju zawodowego nauczyciela, „Annales Universitatis Mariae Curie-Skłodowska. Sectio J”, t. 34, nr 1, s. 9-23.

Weissbrot-Koziarska A., Janik J. (red.) (2006). Profesjonalizm zawodu nauczyciela, Opole: Wydawnictwo Uniwersytetu Opolskiego.

Witkowski L. (2018). Humanistyka stosowana. Wirtuozeria, pasje, inicjacje. Profesje spoteczne versus ekologia kultury, Kraków: Wydawnictwo Wyższej Szkoły Biznesu w Dąbrowie Górniczej.

Ziaziun I.A. (2005). Mistrzostwo pedagogiczne, Radom: Wydawnictwo Instytutu Technologii Eksploatacji PIB.

\section{ADRES DO KORESPONDENCJI}

Dr hab. Barbara Kalinowska-Witek, prof. UMCS

Uniwersytet Marii Curie-Skłodowskiej w Lublinie

Instytut Pedagogiki

e-mail: barbara.kalinowska-witek@poczta.umcs.lublin.pl 